\title{
Polar Constituents and Biological Activity of the Berry-Like Fruits from Hypericum androsaemum L.
}

\begin{abstract}
Giovanni Caprioli ${ }^{1 \dagger}$, Alessia Alunno ${ }^{2}$, Daniela Beghelli ${ }^{3}$, Armandodoriano Bianco ${ }^{4}$, Massimo Bramucci ${ }^{1}$, Claudio Frezza ${ }^{5}$, Romilde lannarelli ${ }^{1+}$, Fabrizio Papa ${ }^{6}$, Luana Quassinti ${ }^{1}$, Gianni Sagratini ${ }^{1}$, Bruno Tirillini ${ }^{7}$, Alessandro Venditti ${ }^{4}, 5$, Sauro Vittori ${ }^{1}$ and Filippo Maggi ${ }^{1 *}$

${ }^{1}$ School of Pharmacy, University of Camerino, Camerino, Italy, ${ }^{2}$ Rheumatology Unit, Department of Medicine, University of Perugia, Perugia, Italy, ${ }^{3}$ School of Bioscience and Veterinary Medicine, University of Camerino, Camerino, Italy, ${ }^{4}$ Department of Chemistry, Sapienza University of Rome, Rome, Italy, ${ }^{5}$ Department of Environmental Biology, Sapienza University of Rome, Rome, Italy, ${ }^{6}$ School of Science and Technology, University of Camerino, Camerino, Italy, ${ }^{7}$ Department of Biomolecular Sciences, University of Urbino, Urbino, Italy
\end{abstract}

OPEN ACCESS

Edited by:

Gregory Franklin

Polish Academy of Sciences, Poland

Reviewed by:

Akira Oikawa,

Yamagata University, Japan

Laxminarain Misra,

Retired from CSIR-CIMAP, India

*Correspondence:

Filippo Maggi

filippo.maggi@unicam.it

${ }^{\dagger}$ These authors have contributed equally to this work

Specialty section

This article was submitted to Plant Metabolism and Chemodiversity,

a section of the journal

Frontiers in Plant Science

Received: 10 December 2015

Accepted: 11 February 2016

Published: 01 March 2016

Citation:

Caprioli G, Alunno A, Beghelli $D$, Bianco A, Bramucci M, Frezza C, lannarelli $R$, Papa F, Quassinti L,

Sagratini $G$, Tirillini $B$, Venditti $A$,

Vittori S and Maggi F (2016) Polar Constituents and Biological Activity of the Berry-Like Fruits from Hypericum androsaemum $L$.

Front. Plant Sci. 7:232. doi: $10.3389 / f p / s .2016 .00232$
Hypericum androsaemum, also known as Tutsan, is a small evergreen shrub common in the Mediterranean basin where it is traditionally used as diuretic and hepatoprotective herbal drug. This plant possesses the peculiarity to produce fleshy and berry-like fruits that ripen from red to shiny black. In the present work, the chemical constituents of methanolic extracts and infusions of red and black fruits were analyzed by HPLC, and correlated with their antioxidant properties which were evaluated by the DPPH, $\beta$-Carotene/linoleic acid, and hypochlorous acid tests. In addition, the red pigment of the fruit was isolated by column chromatography and structurally elucidated by NMR. Results showed that $H$. androsaemum fruits contain high amounts of shikimic and chlorogenic acids, while their color was given by a tetraoxygenated-type xanthone, reported for the first time in Hypericum species. The red berries infusion gave the highest content of total phenolic compounds, DPPH, and hypochlorous acid scavenging activity, and $\beta$-carotene bleaching. Cytotoxicity of the berries extracts on three human tumor cell lines (malignant melanoma, breast adenocarcinoma, and colon carcinoma) was evaluated by

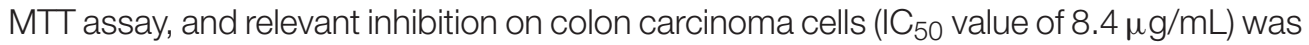
found. Finally, the effects of red berries extract on the immune system were evaluated by peripheral blood mononuclear cell (PBMC) proliferation assay that revealed a strong stimulation on lymphocytes at low doses $(0.4-6 \mu \mathrm{g} / \mathrm{mL})$.

Keywords: Hypericum androsaemum, berry-like fruits, phytochemicals, antioxidant, cytotoxicity, immunomodulatory

\section{INTRODUCTION}

H. androsaemum [Hypericaceae, sect. Androsaemum (Duhamel) Godr.], well known as "tutsan," is a small evergreen shrub fairly common in damp woods and hedgerows (100-1400 m of altitude) within the Mediterranean Basin, mainly in Western and Southern Europe, South-Western Asia, North Africa, while it has been introduced elsewhere (Allen and Hatfield, 2004). The plant possesses big, opposite, sessile, ovate and slightly aromatic leaves bearing translucent glands, but lacking black nodules which are the secretory structures storing naphtodiantrones (Perrone et al., 2013). 
The flowers are large, yellow, with small clearer spots on the petals. Among Hypericum species, the plant has the peculiarity to produce capsules that are not dry at ripening, but become more or less fleshy and berry-like. The ease of cultivation of the plant and the natural color variation in the fresh capsules has been exploited through directed breeding and line selection, resulting in economically highly successful cultivars.

H. androsaemum is used as an important traditional medicine in Europe. For instance, in Portugal its leaves are used as diuretic and to treat liver, kidney and bladder ailments (Valentão et al., 2002). In England, they are mixed with lard to produce an ointment for dressing cuts and wounds (Phillips, 1977; Allen and Hatfield, 2004).

So far, much of the phytochemical and pharmacological studies focused on leaves, revealing the presence of several flavonoids and phenolic acids, mainly chlorogenic acids, and quercetin derivatives which are responsible for the plant hepatoprotective properties (Valentão et al., 2002, 2004). However, scientific works on the showy tutsan's berries were not yet provided. Interestingly, the pigment giving the reddish-black color to the capsular tissue has not yet been identified.

Searching for new fruits with healthy properties, in the present work we reported a comprehensive analysis on the polar constituents and biological activities, namely the antioxidant power, cytotoxicity on tumor cells, and immunomodulatory capacities of $H$. androsaemum berries collected from spontaneous and cultivated plants in central Italy. On the above, we identified the balsamic period during which the berries are richer in active constituents.

\section{MATERIALS AND METHODS}

\section{Plant Material}

Fleshy red and black capsules of $H$. androsaemum were collected in July-August 2014 from cultivated and wild-growing plants from different localities of central Italy belonging to EmiliaRomagna, Marche, and Abruzzo regions (Table 1). Voucher specimens were authenticated and deposited in the Herbarium Universitatis Camerinensis (CAME, included in the online edition of Index Herbariorum c/o School of Biosciences and Veterinary Medicine, University of Camerino, Italy), and archived in the anArchive system for botanical data (anArchive system, http://www.anarchive.it).

\section{Reagents and Standards}

The analytical standards of polyphenols, hypericin, hyperforin, and ascorbic acid were purchased from Sigma-Aldrich (Milano, Italy) and individual stock solutions and standard working solutions were prepared in methanol. HPLC-grade methanol, acetonitrile, acetone, ethyl acetate $(\geq 99.9 \%)$ and phosphoric acid were purchased from Sigma-Aldrich (Milano, Italy). HPLC-grade formic acid was supplied by Merck (Darmstadt, Germany). All solvents and solutions were filtered through 0.45- $\mu \mathrm{m}$ PTFE filters purchased from Phenomenex (Bologna, Italy). For antioxidant assays, 1,1-diphenyl-2-picrylhydrazyl radical (DPPH), butylated hydroxytoluene (BHT), 6-hydroxy-2,5,7,8-tetramethylchroman2 -carboxylic acid (Trolox), Tween 20, $\beta$-carotene, linoleic acid, sodium hypochlorite, taurine, phosphate buffer saline (PBS), and potassium iodide were purchased from Sigma-AldrichFluka (Milan, Italy). Potassium hydroxide, hexane and ethanol were purchased from Sigma-Aldrich (Milan, Italy). Supelco 37 Component FAME Mix was purchased from Supelco (Bellefonte, PA, USA). Anhydrous sodium sulfate was purchased from Fluka-Riedel-deHaën (Milano, Italy) and methanol from Panreac Quimica SA (Barcelona, Spain). Deionized water $(>18 \mathrm{M} \Omega \mathrm{cm}$ resistivity) was obtained from a Milli-Q SP Reagent Water System (Millipore, Bedford, MA, USA).

\section{Preparation of Extracts and Infusions}

The fresh fruits of $H$. androsaemum were grinded using liquid nitrogen. The finely powdered material $(500 \mathrm{mg})$ was extracted with $5 \mathrm{~mL}$ of methanol by sonication $(60 \mathrm{~min}$, at ambient temperature). After centrifugation at $5000 \mathrm{rpm}$ for $10 \mathrm{~min}$, the extracts were transferred to volumetric flask, which was then filled up to $5 \mathrm{~mL}$ with extraction solvent. The sample solutions were filtered through a $0.45 \mu \mathrm{m}$ pore size nylon membrane filter (Phenex, Phenomenex, Torrance, CA, USA) before injection into HPLC-DAD. All samples were stored in a refrigerator at the temperature of $4^{\circ} \mathrm{C}$ until analysis. Each sample was analyzed in triplicate. For tea preparation (water infusion), $5 \mathrm{~g}$ of fresh red and black capsules were treated with boiling water $(100 \mathrm{~mL})$, and infused for $15 \mathrm{~min}$. The obtained liquid was then filtered and cooled. The volume was adjusted to $100 \mathrm{~mL}$ in a volumetric flask. An aliquot of the infusion was then filtered through a $0.45 \mu \mathrm{m}$ membrane and used for HPLC analysis. Each sample was analyzed in triplicate.

\section{HPLC-DAD Analysis}

Analysis of Polyphenols

HPLC-DAD studies were performed using a Hewlett-Packard HP-1090 Series II (Palo Alto, CA, USA), equipped with a vacuum degasser, a binary pump, an autosampler and a model 1046A HP photodiode array detector (DAD). Chromatographic separation was accomplished on a Synergi Polar-RP C18 $(4.6 \times 150 \mathrm{~mm}$, $4 \mu \mathrm{m}$ ) analytical column from Phenomenex (Chesire, UK). The column was preceded by a security cartridge. The mobile phase for HPLC-DAD (diode array detector) analyses was a mixture of (A) water with $0.1 \%$ formic acid $(\mathrm{v} / \mathrm{v})$ and (B) methanol, flowing at $0.7 \mathrm{~mL} / \mathrm{min}$ in isocratic conditions: $60 \% \mathrm{~A}, 40 \% \mathrm{~B}$. The injection volume was $5 \mu \mathrm{L}$. UV spectra were recorded in the range $210-350 \mathrm{~nm}$ for 11 compounds, where $210 \mathrm{~nm}$ was used for quantification of shikimic acid, gallic acid, (+)catechin hydrate, (-)-epicatechin; $310 \mathrm{~nm}$ for $p$-coumaric acid, and trans-resveratrol; 325 for caffeic acid and trans-ferulic acid, 3-O-caffeoylquinic acid, 5-O-caffeoylquinic acid, and 3,5-di-Ocaffeoylquinic acid.

\section{Analysis of Flavonoids, Hypericin, and Hyperforin}

Each extract was chromatographed in reverse phase by an HPLC HP 1090 equipped with an autosampler HP series 1090, ternary pump and DAD detector, following a method previously developed in our research group (Zorzetto et al., 2015). UV/Vis spectra were recorded in the range $210-650 \mathrm{~nm}$, where $210 \mathrm{~nm}$ was used for quantification of rutin, hyperoside, isoquercitrin, 
TABLE 1 | Main information on the investigated "berry-like" fruits of Hypericum androsaemum.

\begin{tabular}{|c|c|c|c|c|c|c|c|}
\hline Color & Sample $\mathbf{N}$. & Region & Collection site & $\begin{array}{l}\text { GPS } \\
\text { coordinates }\end{array}$ & $\begin{array}{l}\text { Altitude } \\
\text { (m a.s.I.) }\end{array}$ & Voucher number ${ }^{a}$ & Habitat \\
\hline \multirow[t]{3}{*}{ Red } & 1 & Emilia Romagna & $\begin{array}{l}\text { ॥l Giardino delle Erbe } \\
\text { (Casola Valsenio) }\end{array}$ & $\begin{array}{l}\text { N } 44^{\circ} 13^{\prime} 48^{\prime \prime} \\
\mathrm{E} 11^{\circ} 37^{\prime} 26^{\prime \prime}\end{array}$ & 265 & CAME 26763 & Cultivated \\
\hline & 2 & Marche & Torrone (Camerino) & $\begin{array}{l}\text { N } 43^{\circ} 15^{\prime} 72^{\prime \prime} \\
\text { E } 13^{\circ} 10^{\prime} 36^{\prime \prime}\end{array}$ & 675 & CAME 26708 & Castanea sativa old coppice \\
\hline & 3 & Marche & Paganico (Camerino) & $\begin{array}{l}\mathrm{N} 43^{\circ} 07^{\prime} 38^{\prime \prime} \\
\mathrm{E} 13^{\circ} 06^{\prime} 30\end{array}$ & 620 & CAME 26934 & Castanea sativa old coppice \\
\hline \multirow[t]{4}{*}{ Black } & 4 & Marche & $\begin{array}{l}\text { University Botanical } \\
\text { Garden (Camerino) }\end{array}$ & $\begin{array}{l}\text { N } 43^{\circ} 08^{\prime} 06^{\prime \prime} \\
\text { E } 13^{\circ} 04^{\prime} 09^{\prime \prime}\end{array}$ & 638 & CAME 26757 & Cultivated \\
\hline & 5 & Marche & Torrone (Camerino) & $\begin{array}{l}\text { N } 43^{\circ} 15^{\prime} 72^{\prime \prime} \\
\mathrm{E} 13^{\circ} 10^{\prime} 36^{\prime \prime}\end{array}$ & 675 & CAME 26708 & $\begin{array}{l}\text { Castanea sativa old coppice and } \\
\text { conifers reforestation }\end{array}$ \\
\hline & 6 & Marche & $\begin{array}{l}\text { Gorgovivo (Serra San } \\
\text { Quirico) }\end{array}$ & $\begin{array}{l}\text { N } 43^{\circ} 26^{\prime} 01^{\prime \prime} \\
\mathrm{E} 13^{\circ} 01^{\prime} 05^{\prime \prime}\end{array}$ & 160 & CAME 26754 & Orno-ostryetum s.l. old coppice \\
\hline & 7 & Abruzzo & $\begin{array}{l}\text { Monte Morrone (Pratola } \\
\text { Peligna) }\end{array}$ & $\begin{array}{l}\text { N } 42^{\circ} 07^{\prime} 16^{\prime \prime} \\
E 13^{\circ} 55^{\prime} 05^{\prime \prime}\end{array}$ & 1005 & CAME 26755 & $\begin{array}{l}\text { Between Quercus cerris forest } \\
\text { and conifers reforestation }\end{array}$ \\
\hline
\end{tabular}

${ }^{a}$ CAME, Herbarium Universitatis Camerinensis, School of Biosciences and Veterinary Medicine, Sect. of Botany and Ecology, University of Camerino (Italy).

quercetin, and quercitrin, $270 \mathrm{~nm}$ for hyperforin, and $590 \mathrm{~nm}$ for hypericin.

\section{Evaluation of Anthocyanins and Betacyanins Occurrence}

The freeze-dried powder $(1 \mathrm{~g})$ of $H$. androsaemum fruits (sample 4) was extracted at room temperature under stirring, twice with $30 \mathrm{~mL}$ of $70 \% \mathrm{EtOH}$ adjusted to $\mathrm{pH} 2.0$ by $\mathrm{HCOOH}$, over $1 \mathrm{~h}$ as total time. The supernatant was filtered, dried under vacuum, and redissolved with 5-10 $\mathrm{mL}$ (exactly measured) of the following mixture: acidic water/acetonitrile/methanol 8:1:1, final $\mathrm{pH} 2.0$, giving a red-brownish color. Sample was then directly analyzed by HPLC/DAD (Mulinacci et al., 2008), but the analyses of the chromatographic profile at $520 \mathrm{~nm}$, the wavelength of choice for monitoring of anthocyanins excluded the presence of this class of compounds. Furthermore, an extraction was carried out with ethanol/water 60:40 on the lyophilized sample; the extract obtained was red-brownish, but once again the analyses in HPLC/DAD excluded the presence of betacyanins.

\section{Method Validation Polyphenols}

Calibration curves of the 11 analyzed compounds (linear range 0.5-100 mg/L), correlation coefficient and LODs and LOQs are reported in Table S1. The obtained recoveries for all compounds, evaluated spiking the samples at two different level of concentration (10 and $50 \mathrm{mg} / \mathrm{L}$ ) with a standard mixture of the 11 compounds, were in the range 92-97 and 99-102\%, respectively, with a $\%$ RSDs $<12 \%(n=5)$ in all cases. Retention time stability was utilized to demonstrate the specificity of the HPLC-DAD method. Reproducibility of the chromatographic retention time for each compound was examined five times per day over a 5 -day period $(n=25)$. The retention times using this method were stable with a percent RSD value of $\leq 1.89 \%$.

\section{Flavonoids, Hypericin, and Hyperforin}

Calibration curves of the eight analyzed compounds (linear range $5-100 \mathrm{mg} / \mathrm{l})$, correlation coefficient, LODs, and LOQs are reported in Table S1. Retention time stability was used to demonstrate the specificity of the HPLC-DAD method. Reproducibility of the chromatographic retention time for each compound was examined five times per day over a 5-day period $(n=25)$. The retention times using this method were stable with a percent $\mathrm{RSD}$ value of $\leq 2.52 \%$.

\section{Estimation of the Total Amount of Phenolic Compounds and Flavonoids}

A modified method of Folin-Ciocalteu, according to Singleton and Rossi (1965) was used for determination of the total amount of phenolics. Seven milliliter of distilled water, $0.5 \mathrm{~mL}$ of FolinCiocalteu reagent and $0.5 \mathrm{~mL}$ of extract (or standard solution of gallic acid) were mixed. After $3 \mathrm{~min}, 2 \mathrm{~mL}$ of $20 \% \mathrm{Na}_{2} \mathrm{CO}_{3}$ were added and incubated in darkness at room temperature for $90 \mathrm{~min}$. The absorbance was measured at $685 \mathrm{~nm}$ and the results expressed in mg of gallic acid/kg fresh fruit. All measures were repeated three times and averaged. The flavonoids content was estimated by the $\mathrm{AlCl}_{3}$ method (Lamaison and Carnat, 1990). One $\mathrm{mL}$ of methanol extract solution was added to $1 \mathrm{~mL}$ of $2 \%$ methanolic $\mathrm{AlCl}_{3} 6 \mathrm{H}_{2} \mathrm{O}$. The absorbance was measured $10 \mathrm{~min}$ later at $430 \mathrm{~nm}$ comparatively to a rutin standard. The results were expressed as mg rutin $/ \mathrm{kg}$ fresh fruit. All measures were repeated three times and the results were averaged.

\section{Isolation and Structural Elucidation of the Fruit Pigment}

The red berries ( $20.0 \mathrm{~g}$, sample 2$)$ were exhaustively extracted with ethanol $96 \%(3 \times 250 \mathrm{~mL})$ for $48 \mathrm{~h}$ and the extracts were gathered altogether and concentrated under reduced pressure obtaining an aqueous sunspension which was further freezedried to recover finally $3.0 \mathrm{~g}$ of crude extract. A portion of the crude extract $(2.0 \mathrm{~g})$ was subjected to a first column chromatography (CC) on silica gel $(60.0 \mathrm{~g})$ using $n$-butanol saturated with water $\left(\mathrm{BuOH} / \mathrm{H}_{2} \mathrm{O} 82: 18 \mathrm{v} / \mathrm{v}\right)$ as eluting system. From this chromatographic run, five compounds were directly identified, i.e., 1,2,3,5-tetrahydroxyxanthone [Fr. 3] (3.9 mg; Trong Tuan et al., 2012), isoquercitrin (Manguro et al., 2003; 
Han et al., 2004), and 7-O-glucosyl luteolin (Lu and Foo, 2000; Chung, 2003) in mixture (3:1) [Fr. 4-9] (42.7 mg), chlorogenic acid (Scarpati et al., 1957; Han et al., 2006), and shikimic acid in mixture (2:1) [Fr. 10-68] (98.0 mg; Xiao et al., 2008). A second column chromatography was, later, performed on the assembly of [Fr.10-68] deriving from this first separation using, this time, as eluting system, a mixture of chloroform/methanol at different concentrations also raising the polarity of the solution during the run in order to elute the most polar compounds which, otherwise, would be left attached to the silica gel. The initial concentration of the mixture was $\mathrm{CHCl}_{3} / \mathrm{MeOH} 85: 15 \mathrm{v} / \mathrm{v}$ and then it was passed respectively to $8: 2 \mathrm{v} / \mathrm{v}, 7: 3 \mathrm{v} / \mathrm{v}$, and lastly to $6: 4 \mathrm{v} / \mathrm{v}$. From this run, shikimic acid [Fr. 4-25] (40.3 mg; Xiao et al., 2008) and chlorogenic acid [Fr. 39-100] (66.8 mg; Scarpati et al., 1957; Han et al., 2006) were better separated each other. The isolated compounds were identified by comparison of experimental NMR spectra with literature data and/or direct comparison with pure compounds available in our laboratory. NMR spectra were recorded on a Varian Mercury $300 \mathrm{MHz}$ and/or on a Bruker Avance II $400 \mathrm{MHz}$ instrument using $\mathrm{CDCl}_{3}$, $\mathrm{CD}_{3} \mathrm{OD}$, or $\mathrm{D}_{2} \mathrm{O}$ as deuterated solvents; the chemical shift was expressed in ppm from TMS. MS spectra were performed on a Q-TOF MICRO spectrometer (Micromass, now Waters, Manchester, UK) equipped with an ESI source, that was operated in the negative and/or positive ion mode. The flow rate of sample infusion was $10 \mu \mathrm{L} / \mathrm{min}$ with 100 acquisitions per spectrum. Data were analyzed using the MassLynx software developed by Waters.

1,2,3,5-tetrahydroxyxanthone: ${ }^{1} \mathrm{H}$ NMR (300 $\left.\mathrm{MHz}, \mathrm{CD}_{3} \mathrm{OD}\right)$ $\delta: 7.92(1 \mathrm{H}, \mathrm{d}, J=7.8 \mathrm{~Hz}, \mathrm{H}-8), 7.63(1 \mathrm{H}, \mathrm{m}, \mathrm{H}-7), 7.44(1 \mathrm{H}, \mathrm{d}$, $J=7.8 \mathrm{~Hz}, \mathrm{H}-6), 6.33$ (1H, s, H-4). ESI-MS: $m / z$ [M-H] ${ }^{-} 259.07$.

isoquercitrin: ${ }^{1} \mathrm{H} \mathrm{NMR}\left(300 \mathrm{MHz}, \mathrm{CD}_{3} \mathrm{OD}\right) \delta: 7.89(1 \mathrm{H}, \mathrm{s}, \mathrm{H}-$ $\left.2^{\prime}\right), 7.67\left(1 \mathrm{H}, \mathrm{d}, J=8.0 \mathrm{~Hz}, \mathrm{H}-6^{\prime}\right), 6.82\left(1 \mathrm{H}, \mathrm{d}, J=8.0 \mathrm{~Hz}, \mathrm{H}-5^{\prime}\right)$, $6.46(1 \mathrm{H}$, br s, H-8), $6.17(1 \mathrm{H}$, br s, H-6), $5.15(1 \mathrm{H}, \mathrm{d}, J=7.6 \mathrm{~Hz}$, $\left.\mathrm{H}-1^{\prime \prime}\right), 3.96\left(1 \mathrm{H}, \mathrm{d}, J=12.0 \mathrm{~Hz}, \mathrm{H}-6 \alpha^{\prime \prime}\right), 3.74(1 \mathrm{H}, \mathrm{dd} J=12.0$, $\left.5.8 \mathrm{~Hz}, \mathrm{H}-6 \beta^{\prime \prime}\right)$. ESI-MS: $m / z[\mathrm{M}+\mathrm{Na}]^{+} 486.87$.

7-O-glucosyl luteolin: ${ }^{1} \mathrm{H}$ NMR (300 $\left.\mathrm{MHz}, \mathrm{CD}_{3} \mathrm{OD}\right) \delta: 7.39$ $(1 \mathrm{H}$, br s, H-2 $), 7.58(1 \mathrm{H}$, br s, H-5 $), 7.07(1 \mathrm{H}, \mathrm{d}, J=8.5 \mathrm{~Hz}, \mathrm{H}-$ $\left.6^{\prime}\right), 6.87(1 \mathrm{H}, \mathrm{s}, \mathrm{H}-6), 6.46(1 \mathrm{H}, \mathrm{br} \mathrm{s}, \mathrm{H}-8), 5.34(1 \mathrm{H}, \mathrm{d}, J=5.4 \mathrm{~Hz}$, H-1" ${ }^{\prime \prime}$. ESI-MS: $m / z[\mathrm{M}+\mathrm{K}]^{+} 486.95$.

chlorogenic acid: ${ }^{1} \mathrm{H}$ NMR $\left(\mathrm{CD}_{3} \mathrm{OD}\right.$ a $\left.300 \mathrm{MHz}\right) \delta: 7.57(1 \mathrm{H}$, d, $J=15.9 \mathrm{~Hz}, \mathrm{H}-10), 7.03$ (1H, br s, H-12), 6.93 (2H, m, H-15 to $\mathrm{H}-16), 6.28(1 \mathrm{H}, \mathrm{d}, J=15.9 \mathrm{~Hz}, \mathrm{H}-9), 5.35(1 \mathrm{H}, \mathrm{m}, \mathrm{H}-3), 4.37$ (1H, m, H-4), 3.67 (1H, m, H-5), 2.37-1.86 (4H, m, H-2 to H-6). ESI-MS: $m / z[\mathrm{M}+\mathrm{Na}]^{+} 376.98 ; m / z[\mathrm{M}-\mathrm{H}]^{-} 353.21$.

shikimic acid: ${ }^{1} \mathrm{H}$ NMR $\left(300 \mathrm{MHz}, \mathrm{CD}_{3} \mathrm{OD}\right), \delta: 6.63(1 \mathrm{H}, \mathrm{m}$, $\mathrm{H}-2), 4.32(1 \mathrm{H}$, br t, $J=3.9 \mathrm{~Hz}, \mathrm{H}-3), 3.94(1 \mathrm{H}, \mathrm{ddd}, J=7.6,6.3$, 5.2, Hz, H-5), $3.59(1 \mathrm{H}, \mathrm{dd}, J=7.6,3.9 \mathrm{~Hz}, \mathrm{H}-4), 2.77(1 \mathrm{H}, \mathrm{dd}$, $J=17.7,5.2 \mathrm{~Hz}, \mathrm{H}-6 \alpha), 2.18(1 \mathrm{H}, \mathrm{dd}, J=17.7,6.3, \mathrm{~Hz} \mathrm{H}-6 \beta)$. ESI-MS: $m / z[\mathrm{M}-\mathrm{H}]^{-} 173.11$.

\section{Determination of the Antioxidant Activity 1,1-diphenyl-2-picrylhydrazyl (DPPH) Radical-Scavenging Activity}

The antiradical activity was determined by the DPPH radical-scavenging method (Peterson et al., 2002). Each sample was mixed with $900 \mu \mathrm{L}$ of $100 \mathrm{mM}$ Tris- $\mathrm{HCl}$ buffer, $\mathrm{pH} 7.4$, and then added to $1 \mathrm{~mL}$ of $0.5 \mathrm{mM}$ DPPH in methanol $(250 \mu \mathrm{M}$ in the reaction mixture). The control sample was prepared using methanol. Trolox was employed as a standard antioxidant to examine the radical-scavenging activities. Absorbances of the mixtures were measured at $517 \mathrm{~nm}$. The activity was calculated as $\mathrm{IC}_{50}$. All tests and analyses were run in triplicate and averaged.

\section{B-Carotene/Linoleic Acid Assay}

In this assay, the antioxidant capacity was determined by measuring the inhibition of the volatile organic compounds and the conjugated diene hydroperoxides arising from linoleic acid oxidation (Dapkevicius et al., 1998). A stock solution of $\beta$ carotene/linoleic acid mixture was prepared as follows: $0.5 \mathrm{mg}$ of $\beta$-carotene was dissolved in $1 \mathrm{~mL}$ of chloroform, then $25 \mu \mathrm{L}$ of linoleic acid and $200 \mathrm{mg}$ of Tween 40 were added. Then, $100 \mathrm{~mL}$ distilled water saturated with oxygen $(30 \mathrm{~min}, 100 \mathrm{~mL} / \mathrm{min}$ ) was added; $2.5 \mathrm{~mL}$ of this reaction mixture were dispensed into test tubes and $100 \mu \mathrm{L}$ portions of variable concentrations of the samples were added; the emulsion system was incubated for up to $48 \mathrm{~h}$ at $37^{\circ} \mathrm{C}$. The same procedure was repeated with the synthetic antioxidant butylated hydroxytoluene (BHT) and Trolox as positive controls, and the blank. After incubation, absorbances of the mixtures were measured at $490 \mathrm{~nm}$. The activity was calculated as $\mathrm{IC}_{50}$. All tests and analyses were run in triplicate and averaged.

\section{Hypochlorous Acid Scavenging ( $\mathrm{HOCl})$}

The amount of $\mathrm{HOCl}$ was measured by the chlorination of taurine (Weiss et al., 1982). One hundred microliters of sodium hypochlorite $(600 \mathrm{mM})$ were added to $100 \mu \mathrm{L}$ of taurine $(150 \mathrm{mM})$ and $100 \mu \mathrm{L}$ of variable concentrations of sample in $\mathrm{PBS}$ at $\mathrm{pH}$ 7.4. Absorbance was measured at $350 \mathrm{~nm}$ after the addition of $100 \mu \mathrm{L}$ of $2 \mathrm{M}$ potassium iodide. The activity was calculated as $\mathrm{IC}_{50}$. Trolox was used as the positive control. All tests and analyses were run in triplicate and averaged.

\section{Cytotoxic Activity}

A375 (human malignant melanoma cells) and MDA-MB 231 cells (human breast adenocarcinoma cells) were cultured in Dulbecco's Modified Eagle's Medium (DMEM) with $2 \mathrm{mM} \mathrm{L-}$ glutamine, $100 \mathrm{IU} / \mathrm{mL}$ penicillin, $100 \mu \mathrm{g} / \mathrm{mL}$ streptomycin, and supplemented with $10 \%$ heat-inactivated fetal bovine serum (HI-FBS). HCT116 cells (human colon carcinoma cells), were cultured in RPMI1640 medium with $2 \mathrm{mM}$ L-glutamine, 100 $\mathrm{IU} / \mathrm{mL}$ penicillin, $100 \mu \mathrm{g} / \mathrm{mL}$ streptomycin, and supplemented with $10 \%$ HI-FBS. Cells medium and solutions were from PAA Laboratories $\mathrm{GmbH}$, Austria. Cells were cultured in a humidified atmosphere at $37^{\circ} \mathrm{C}$ in presence of $5 \% \mathrm{CO}_{2}$. The MTT assay was used as a relative measure of cell viability. Cell-viability assays were carried out as described (Quassinti et al., 2013). Briefly, cells were seeded at the density of $2 \times$ $10^{4}$ cells $/ \mathrm{mL}$. After $24 \mathrm{~h}$, samples were exposed to different concentrations of $H$. androsaemum fruits methanolic extracts $(1.56-200 \mu \mathrm{g} / \mathrm{mL})$. Cells were incubated for $72 \mathrm{~h}$ in a humidified atmosphere of $5 \% \mathrm{CO}_{2}$ at $37^{\circ} \mathrm{C}$. Cisplatin (Sigma) was used as the positive control. At the end of incubation, each well received $10 \mu \mathrm{L}$ of 3-(4,5-dimethyl-2-thiazolyl)-2,5-diphenyl-2Htetrazoliumbromide (MTT) $(5 \mathrm{mg} / \mathrm{mL}$ in phosphate-buffered 
saline, PBS) and the plates were incubated for $4 \mathrm{~h}$ at $37^{\circ} \mathrm{C}$. The extent of MTT reduction was measured spectrophotometrically at $540 \mathrm{~nm}$ using a Titertek Multiscan microElisa (Labsystems, FIHelsinki). Experiments were conducted in triplicate. Cytotoxicity is expressed as the concentration of berries extract inhibiting cell growth by $50 \%\left(\mathrm{IC}_{50}\right)$. The $\mathrm{IC}_{50}$ values were determined with GraphPad Prism 4 computer program (GraphPad Software, S. Diego, CA, USA).

\section{Immunomodulatory Activity}

Peripheral blood mononuclear cell (PBMC) proliferation assay was performed by flow cytometry on pig lymphocytes isolated from fresh heparinized blood samples $(20 \mathrm{~mL} / \mathrm{pig})$.

The blood donors (Danish pigs, weighing 80-90 kg) were conventionally reared in a hilly area of Umbria (Rustici Farm, Parco del Subasio, Assisi, Italy) and the same were not subjected to none experimental protocol. For this reason this study is exempt from the ethics committee approval (DL 2014/26, Art. 2, comma 1,f). However, the blood samplings have been collected (only one time) with the farmer 's consent, handling the animals in accordance with the recommendations of the Directive 2010/63/EU of the European Parliament and of the Council of the European Union for the protection of animals used for scientific purposes. The number of live lymphocytes, suspended in complete RPMI-1640 medium (Euroclone ${ }^{\circledR}$ ) that contained $10 \%$ heat-inactivated pig serum, L-glutammine $(2 \mathrm{mM}$; Euroclone $\left.{ }^{\circledR}\right)$, penicillin $\left(100 \mathrm{U} / \mathrm{mL}\right.$; Biochrom ${ }^{\mathrm{AG}}$, Berlin), and streptomycin $\left(100 \mu \mathrm{g} / \mathrm{mL}\right.$; Biochrom ${ }^{\mathrm{AG}}$, Berlin), was determined using a counting chamber and a trypan blue dye exclusion procedure. The final concentration of live cells was adjusted to $2 \times 10^{6} / \mathrm{mL}$ in complete medium and $100 \mu \mathrm{L}$ of suspension/well $\left(2 \times 10^{5}\right.$ live cells $)$ were dispensed in flat bottom 96-well tissue culture plates (Becton Dickinson, Lincoln Park, NJ). For the measurement of cell proliferation, the PBMC were prestained with carboxyfluorescein diacetate succinimydyl ester (CFSE) cell tracer (BioLegend, San Diego, CA) and cultured for 5 days at $37^{\circ} \mathrm{C}$ in $5 \% \mathrm{CO}_{2}$. Proliferation stimuli were $1 \mu \mathrm{g} / \mathrm{mL}$ of pokeweed mitogen (PWM, it stimulates the B lymphocyte only in the presence of T cells; Sigma-Aldrich) or $1.2 \mu \mathrm{g} / \mathrm{mL}$ of phytohemagglutinin (PHA, a polyclonal T-cell activator; Biochrom $^{\mathrm{AG}}$, Berlin) in presence or absence of different dilutions of methanolic extract from red berries. The first assay was conducted analysing three different concentrations of red berries methanolic extract, starting from its $\mathrm{IC}_{50}$ higher dosage (i.e., 20, 10 , and $6 \mu \mathrm{g} / \mathrm{mL}$, respectively). The second assay was conducted further analyzing lower concentrations of $H$. androsaemum extract (i.e., 1.2, 0.8, and $0.4 \mu \mathrm{g} / \mathrm{mL}$, respectively). Each culture condition was repeated in triplicate. The fruit extract was initially diluted 1:100 (v/v) in ethanol, and further dilutions were made in HBSS (Gibco ${ }^{\circledR}$, Life Technologies Italia). Finally, medium volume was adjusted to $200 \mu \mathrm{L} /$ well. A negative control was represented by PBMC cultured without any mitogen/activator (CTR), so that the base proliferation could be estimated (Liu et al., 1996). With each cell division, the intensity of CFSE staining is reduced of a half and lymphocyte proliferation is calculated as frequency of CFSE ${ }^{\text {low }}$ cells within gated cell population compared to intensity of parent population. Flow cytometry analyses were performed on a standard FACSCalibur ${ }^{\mathrm{TM}}$ flow cytometer (Becton Dickinson, Mountain View, CA) operated by the CELLQuestPro ${ }^{\mathrm{TM}}$ software. Within a tight lymphocyte gate, 10,000 cells were acquired and the data were saved in the list mode. Cells from each culture condition were pooled and analyzed together. The percentage of increased proliferation vs. the basal values (PI) were calculated by the following formula:

$$
(\mathrm{B}-\mathrm{A}) / \mathrm{A}^{*} 100
$$

where, B is represented by the percentage of proliferation obtained by cells stimulated with the mitogen/activator \pm fruit extract (the CTR-B was stimulated only with fruit extract), whereas $\mathrm{A}$ is represented by the percentage of proliferation obtained by cells stimulated or not (CTR) with the mitogen/activator, without fruit extract.

\section{RESULTS AND DISCUSSION Analysis of Polar Constituents in $H$. androsaemum Fruit and Infusions}

From the analysis of $H$. androsaemum fruits methanolic extracts performed with the first method developed, we identified and quantified simultaneously 11 compounds, mainly polyphenols, i.e., shikimic acid, gallic acid, catechin hydrate, epicatechin, p-coumaric acid, trans-resveratrol, caffeic acid, trans-ferulic acid, chlorogenic acid, neochlorogenic acid, and 3,5-di-Ocaffeoylquinic acid, meanwhile with the second method, we identified and quantified simultaneously seven compounds among flavonoids naphtodianthrones and phloroglucinols, i.e., rutin, quercetin, quercitrin, isoquercitrin, hyperoside, hypericin, and hyperforin.

In Table 2, the quantitative determination of the 18 analyzed compounds in the seven $H$. androsaemum fruit samples and in two infusions obtained from red and black "berry-like" capsules is reported. Shikimic acid, chlorogenic acid, rutin, and hyperoside, were present in all samples analyzed meanwhile neochlorogenic acid and isoquercetrin were not found only in black sample 5 . Catechin was present only in the three red samples analyzed and in one black fruit sample (7), while epicatechin was present in the three red fruits but also in one black sample (6), even if in a very low concentration. Shikimic acid was found at high levels in all samples, ranging from 0.805 to $12.799 \mathrm{mg} / \mathrm{g}$ dry weight. It was found in higher concentration in red fruits $(8.187-12.799 \mathrm{mg} / \mathrm{g})$ than in black ones $(0.805-5.988 \mathrm{mg} / \mathrm{g})$. This compound is the biosynthetic precursor of aromatic amino acids and phenolic compounds and is endowed with important biological properties such as antiviral, anti-inflammatory, antiplatelet aggregation, and prevention of brain damage after ischemia. Shikimic acid was never reported in $H$. androsaemum leaves in previous studies.

Chlorogenic acid was the second most abundant fruit constituent, ranging from 0.099 to $14.553 \mathrm{mg} / \mathrm{g}$. The lowest amount was detected in black fruit $(0.099 \mathrm{mg} / \mathrm{g}$ in sample 5) and the highest amount in the three red fruit samples, i.e., $14.553 \mathrm{mg} / \mathrm{g}$ in sample $1,7.035 \mathrm{mg} / \mathrm{g}$ in sample 2, and $6.811 \mathrm{mg} / \mathrm{g}$ in sample 3 . The high levels of chlorogenic acid found in this 
TABLE 2 | Quantitative determination of the analyzed compounds in six $H$. androsaemum fruit samples (mg/g dry weight) and in two infusions (mg/L) obtained from red and black "berry-like" capsules; relative standard deviations were in a range from 0.10 to 5.88 ( $n=3$ ).

\begin{tabular}{|c|c|c|c|c|c|c|c|c|c|}
\hline \multirow[t]{3}{*}{ Constituent (mg/g dry fruit) } & \multicolumn{7}{|c|}{ Fruits (mg/g) } & \multicolumn{2}{|c|}{ Infusion (mg/L) } \\
\hline & \multicolumn{3}{|c|}{ Red } & \multicolumn{4}{|c|}{ Black } & \multirow[b]{2}{*}{ Red (2) } & \multirow[b]{2}{*}{ Black (5) } \\
\hline & 1 & 2 & 3 & 4 & 5 & 6 & 7 & & \\
\hline Shikimic acid & 12.799 & 10.203 & 8.187 & 1.235 & 1.182 & 0.805 & 5.988 & 208.0 & 29.5 \\
\hline Gallic acid & nd & nd & nd & nd & 0.044 & nd & 0.032 & nd & 4.6 \\
\hline Caffeic acid & nd & nd & nd & nd & nd & nd & nd & nd & nd \\
\hline Cumaric acid & nd & nd & nd & nd & nd & nd & nd & nd & nd \\
\hline Ferulic acid & nd & nd & nd & nd & nd & nd & 0.123 & 15.0 & nd \\
\hline Chlorogenic acid & 14.553 & 7.035 & 6.811 & 2.029 & 0.099 & 0.441 & 0.887 & 422.0 & 8.4 \\
\hline Neochlorogenic acid & 6.587 & 0.662 & 0.122 & 0.312 & nd & 0.008 & 0.035 & nd & 0.6 \\
\hline 3,5-dicaffeoylquinic acid & 0.208 & 0.340 & nd & nd & nd & nd & nd & nd & nd \\
\hline Catechin & 0.114 & 0.063 & 0.083 & nd & nd & nd & 0.068 & nd & 23.2 \\
\hline Epicatechin & 0.521 & 0.680 & 0.300 & nd & nd & 0.001 & nd & 25.0 & nd \\
\hline Rutin & 0.233 & 0.662 & 0.008 & 0.039 & 0.014 & 0.023 & 0.011 & 27.0 & nd \\
\hline Hyperoside & 0.662 & 0.053 & 0.004 & 0.247 & 0.015 & 0.012 & 0.029 & 21.6 & nd \\
\hline Isoquercetrin & 0.179 & 0.106 & 0.004 & 0.078 & nd & 0.007 & 0.063 & 8.76 & nd \\
\hline Quercitrin & nd & 0.113 & 0.017 & nd & 0.005 & 0.012 & 0.132 & 9.38 & 3.57 \\
\hline Quercetin & nd & nd & nd & nd & nd & nd & nd & nd & nd \\
\hline Resveratrol & nd & nd & nd & nd & nd & nd & nd & nd & nd \\
\hline Hyperforin & nd & nd & nd & nd & nd & nd & nd & nd & nd \\
\hline Hypericin & nd & nd & nd & nd & nd & nd & nd & nd & nd \\
\hline
\end{tabular}

nd, not detected.

study are of great interest for a potential application of the berries of $H$. androsaemum as a functional food. Chlorogenic acid is a hydroxycinnamic acid derivative widespread in plants, fruits and vegetables, among which coffee beans are the main source. This compound has attracted attention of nutritionists because it has been proven to inhibit carcinogenesis, to protect against oxidative stress, to improve the glucose metabolism, to reduce the risk of cardiovascular disease, and to exhibit antiobesity effects (Cho et al., 2010). Moreover, its abundance may also confirm the traditional uses of the plant as a wound healing agent (Allen and Hatfield, 2004). In fact, Chen et al. (2013) have demonstrated that topical application of chlorogenic acid can accelerate the process of excision wound healing by its ability to increase collagen synthesis through up-regulation of key players such as tumor necrosis factor- $\alpha$ and transforming growth factor- $\beta 1$ in different phases of wound healing as well as by its antioxidant potential. Among the other compounds of chlorogenic acid family, neochlorogenic acid was quite abundant, ranging from 0.008 to $6.587 \mathrm{mg} / \mathrm{g}$ in the seven fruit samples. The lowest amount was detected in black fruits (sample 6) and the highest in red fruits (sample 1). Instead, 3,5-dicaffeoyilquinic acid was only present in red fruits $(0.208 \mathrm{mg} / \mathrm{g}$ in sample 1 and $0.340 \mathrm{mg} / \mathrm{g}$ in sample 2). The concentrations of the caffeoylquinic acids found in the berries extracts were slightly lower with respect to those reported for water infusions of leaves (Valentão et al., 2004). In particular the latter showed neochlorogenic acid more abundant than chlorogenic acid, and high level of quercetin, which instead was missing in berries.
As mentioned above, catechin was present only in the three red fruits analyzed, ranging from $0.066 \mathrm{mg} / \mathrm{g}$ in sample 2 to $0.114 \mathrm{mg} / \mathrm{g}$ in sample 1 , and in one sample (7) of black fruits $(0.068 \mathrm{mg} / \mathrm{g})$. Epicatechin amounts ranged from $0.001 \mathrm{mg} / \mathrm{g}$ in black fruits (sample 6) to $0.680 \mathrm{mg} / \mathrm{g}$ in red fruits (sample 2). The highest levels of these two flavanols, which are believed to possess strong antioxidant activity, were comparable with those previously found in the leaves (Dopico-Garcia et al., 2011).

Among flavonoids, rutin was abundant in red fruits, ranging from 0.008 in sample 3 to $0.662 \mathrm{mg} / \mathrm{g}$ in sample 2 . On the contrary, it was present in low amount in black fruits, ranging from 0.011 in sample 7 to $0.039 \mathrm{mg} / \mathrm{g}$ in sample 4 . Although high, these levels were lower than those reported in other Hypericum species such as $H$. perforatum $(4.25-9.23 \mathrm{mg} / \mathrm{g})$, and H. hyssopifolium $(12.42 \mathrm{mg} / \mathrm{g})$, both growing in central Italy (Sagratini et al., 2008). This flavonoid was not reported in leaves of $H$. androsaemum.

Also hyperoside and isoquercitrin were present at high levels in red fruits, especially in sample 1 (0.662 and 0.179 $\mathrm{mg} / \mathrm{g}$, respectively), and in sample $2(0.053$ and $0.106 \mathrm{mg} / \mathrm{g}$, respectively). These metabolites were already detected in leaves, although in trace amounts (Valentão et al., 2002). By the way, their levels were lower with respect to those found in other species belonging to the sect. Androsaemum like H. grandifolium (1.7 mg/g) and H. hircinum (1.3 mg/g; Bonkanka et al., 2008; Sagratini et al., 2008).

Quercitrin was found in two red fruit samples, such as sample $2(0.113 \mathrm{mg} / \mathrm{g})$ and sample $3(0.017 \mathrm{mg} / \mathrm{g})$, and in three black fruit 
samples, such as sample $5(0.005 \mathrm{mg} / \mathrm{g})$, sample $6(0.012 \mathrm{mg} / \mathrm{g})$, and sample $7(0.132 \mathrm{mg} / \mathrm{g})$. Also this compound was never detected in $H$. androsaemum leaves.

The HPLC-DAD method employed did not allow to detect both hypericin and hyperforin in the $H$. androsaemum fruits. The absence of hypericin, and of naphtodianthrones in general, is supported by the lack of black nodules which are the secretory structures storing naphtodianthrones. As a matter of fact, hypericin was never detected in the whole plant as well (Kitanov, 2001). Regarding hyperforin, other studies confirmed its absence from $H$. androsaemum (Aziz et al., 2006).

The performed analysis clearly showed that red fruits contained more constituents and in higher amount with respect to black ones, although some differences among samples according to the geographical origin were evidenced (Table 2). Samples 1, 2, and 3 of red fruits contained 9, 10, and 9 of the investigated analytes, respectively. Among black fruits, sample 7 was the richer with seven compounds. Overall, the fruits of $H$. androsaemum showed to be a rich source of shikimic acid. Moreover, they were richer in chlorogenic acid and poorer in neo-chlorogenic acid with respect to leaves previously analyzed (Valentão et al., 2004), while they lack quercetin which instead was found as the most abundant flavonoid in leaves (DopicoGarcia et al., 2011). On the other hand, fruits showed levels of the flavanols catechin and epicathechin comparable to those of leaves (Dopico-Garcia et al., 2011).

From the analyses of the two infusions obtained from red and black "berry-like" capsules, it emerged that the former contained a high number of the investigated analytes ( 8 out of the 18 monitored) and at a quite high level (Table 2). In fact, the infusion obtained from red fruits was rich in chlorogenic acid $(422 \mathrm{mg} / \mathrm{L})$ and shikimic acid $(208 \mathrm{mg} / \mathrm{L})$, followed by rutin $(27 \mathrm{mg} / \mathrm{L})$, epicatechin $(25 \mathrm{mg} / \mathrm{L})$, and hyperoside $(21.6 \mathrm{mg} / \mathrm{L})$, while ferulic acid, quercitrin, and isoquercitrin were found at low concentrations ( $\leq 15 \mathrm{mg} / \mathrm{L})$. On the other hand, the infusions obtained from black berries contained a lower number of the investigated analytes ( 6 out of 18 compounds) and in a very low level $(<30 \mathrm{mg} / \mathrm{L})$. In black berries infusion shikimic acid was the most abundant compound with a concentration of $29.5 \mathrm{mg} / \mathrm{L}$. Surprisingly, catechin but not epicatechin was detected $(23.2 \mathrm{mg} / \mathrm{L})$. Overall, the analysis of infusions supported those performed on methanolic extracts and confirmed that red berries of $H$. androsaemum are to be preferred to black ones as a source of shikimic acid and phenolic compounds. The level of chlorogenic acid found in the infusion from red berries is particular interesting, since the concentration $(422 \mathrm{mg} / \mathrm{L})$ was comparable to that obtained in a cup of espresso coffee (Caprioli et al., 2013), in which it ranged from 394.9 to $555.8 \mathrm{mg} / \mathrm{L}$, depending on the different ways of preparation. Also when compared with berry fruits such as blueberries, blackberries, and raspberries, tutsan fruits showed higher levels of chlorogenic acids (Clifford, 1999).

\section{Determination of the Fruit Pigment}

The chromatographic separation of the ethanolic extract obtained from the red berries of $H$. androsaemum confirmed that chlorogenic and shikimic acids were the most abundant polar compounds. On the other hand, among the minor components we evidenced several molecules with aromatic structure such as glycosidic flavonoids (i.e., isoquercitrin and 7-O-glucosyl luteolin) and a xanthone never reported before in Hypericum species. The latter was identified as 1,2,3,5-tetrahydroxyxanthone (Figure 1), and its presence in $H$. androsaemum could be of taxonomic interest. This compound was previously found in Polygala karensium (Trong Tuan et al., 2012), a species belonging to Polygalaceae family. Previously, hydroxy and methoxy substituted xanthones were isolated from roots of $H$. androsaemum (Nielsen and Arends, 1979), while in calli and suspended cells cultures of the same species 1,3,5,6 and 1,3,6,7 oxygenated xanthones (Dias et al., 2000), along with prenylated xanthone aglycones and their glucosides were characterized (Schmidt et al., 2000). Therefore, the occurrence of this xanthone in the genus Hypericum is remarkable. Although xanthones are less abundant in the genus Hypericum and more in general in nature in comparison with other phenolic compounds, they showed several biological properties, such as strong and selective inhibition of MAO-A, in vitro toxicity, in vivo antitumor activity, as well as anti-inflammatory, antibacterial, and antifungal activities (Demirkiran, 2007).

The presence of mixture of all these aromatic compounds (i.e., flavonoids and xanthone) in the fruit pericarp, may contribute to the observed color of the fleshy capsule and extracts of $H$. androsaemum.

\section{Determination of Total Phenolics and Flavonoids Content, and of Antioxidant Capacity of $\boldsymbol{H}$. androsaemum Berries}

The methanolic extracts from berries of $H$. androsaemum in almost all cases exhibited a significant high content in phenolics ranging from $1448 \mathrm{mg}$ gallic acid equivalent (GAE)/kg in black fruits (sample 5) to $8530 \mathrm{mg} \mathrm{GAE} / \mathrm{kg}$ in red berries (sample 2; Table 3). Much higher was the phenol content in tea infusions, with values of $8744 \mathrm{mg} \mathrm{GAE} / \mathrm{kg}$ for black berries and, more important, of $18145 \mathrm{mg} \mathrm{GAE} / \mathrm{kg}$ for red berries. The total phenols and the total flavonoids were "extracted" better with an infusion procedure than with a methanolic extraction. Therefore, the red fruits showed higher amounts of phenols and flavonoids than black ones, i.e., ripening lowered the phenolic content.

On the basis of classification of fruits and vegetables depending on the total phenolic content, namely high (>2000 mg GAE/kg), medium (1000-2000 mg GAE/kg) and low (<1000 mg $\mathrm{GAE} / \mathrm{kg}$ ), the examined samples of berries fruits took place mainly in the first group. Interestingly, in almost all cases the total phenolic content of tutsan berries was higher than that of strawberry (1127 mg GAE/kg), mandarin (1161 mg GAE/kg), blueberry (2196 mg GAE/kg), and sour cherry (2560 mg GAE/kg; Dragović-Uzelac et al., 2009).

The chemical complexity of the extracts or infusions, often mixtures of many compounds with differences in functional groups, polarity, and chemical behavior, could lead to scattered results, depending on the antioxidant test employed. Therefore, an approach with multiple assays in screening work is highly advisable. The $H$. androsaemum berries were screened for 
<smiles>[R20]c1cc(O)c2c(=O)c([R2])c(-c3ccc(O)c(O)c3)oc2c1</smiles>

$\mathrm{R}_{1}=\mathrm{Glc} ; \mathrm{R}_{2}=\mathrm{H}:$ 7-O-glucosyl luteolin

$R_{1}=H ; R_{2}=$ OGlc : isoquercitrin<smiles>O=c1c2cccc(O)c2oc2cc(O)c(O)c(O)c12</smiles>

\section{1,2,3,5-tetrahydroxyxanthone}<smiles>O=C(O)C1=C[C@@H](O)[C@H](O)C(O)C1</smiles>

shikimic acid<smiles>O=C(/C=C/c1ccc(O)c(O)c1)OC1C[C@](O)(C(=O)O)C[C@H](O)[C@H]1O</smiles>

chlorogenic acid

FIGURE 1 | Structures of polar compounds isolated from the red berries of Hypericum androsaemum.

TABLE 3 | Antioxidant activity, total phenols, and total flavonoids in methanolic extracts and infusions of red and black berries of $\boldsymbol{H}$. androsaemum.

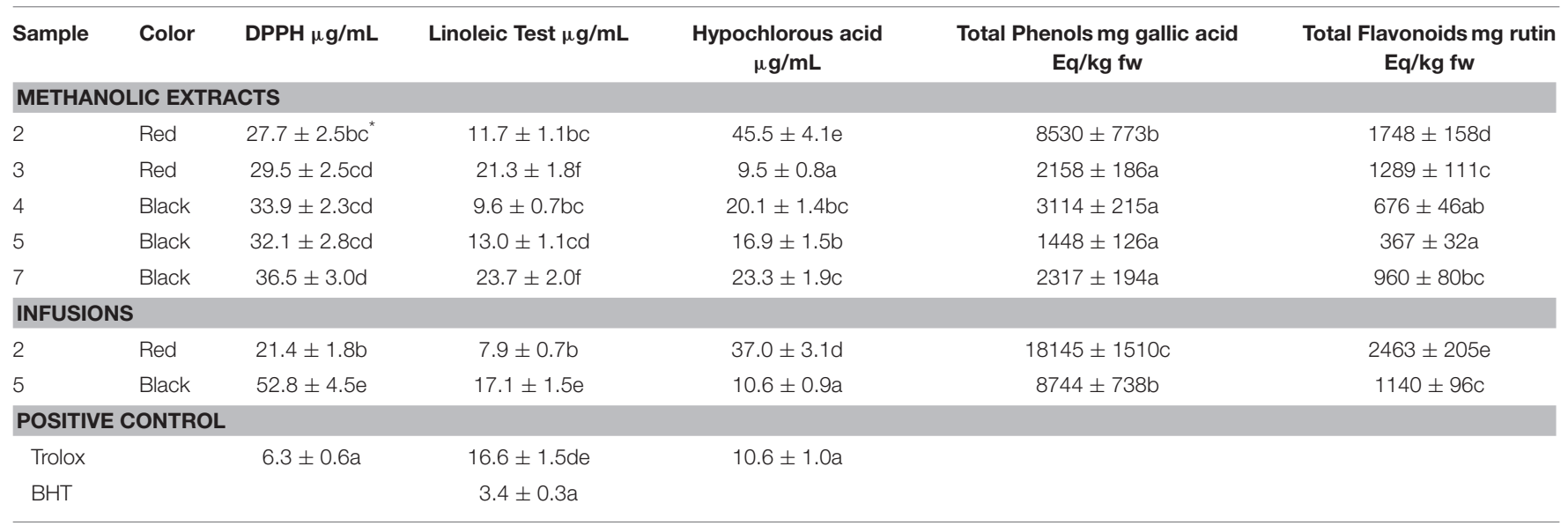

*Values within a column for each sample having different letters are significantly different from each other using Tukey's LSD test $(p<0.05)$.

their possible antioxidant activity by three non-enzymatic test systems: 1,1-diphenyl-2-picrylhydrazyl (DPPH) radicalscavenging, $\beta$-carotene/linoleic acid assay, and hypochlorous acid scavenging ( $\mathrm{HOCl})$. All methanolic extracts and tea infusions of berry-like fruits of $H$. androsaemum showed a significant radical scavenging activity with $\mathrm{IC}_{50}$ values in the range 21.4$52.8 \mu \mathrm{g} / \mathrm{mL}$ (Table 3). Methanolic extracts displayed similar inhibition on DPPH. Compared with activity of Trolox, the methanolic extracts showed an activity only 4.4-5.8 lower than that of the positive control. Water infusion from red berries was by far the most active with an $\mathrm{IC}_{50}$ value of $21.4 \mu \mathrm{g} / \mathrm{mL}$, only 3.4 times higher than that of Trolox. This activity seemed to be related to the higher content of total phenolics (18145 mg GA $\mathrm{Eq} / \mathrm{kg}$ ).

The antioxidant activity of tutsan berries was evaluated by the $\beta$-carotene-linoleic acid test, using BHT as positive control. For the methanolic extracts we obtained $\mathrm{IC}_{50}$ values in the range 9.6$23.7 \mu \mathrm{g} / \mathrm{mL}$ which were 2.8-6.9 times higher than that of BHT. This activity did not depend on the ripening rate, but appeared to be correlated to the different geographic origin of the samples. Instead, water infusions displayed the same kind of inhibition seen on DPPH, with those prepared with red berries $\left(\mathrm{IC}_{50}\right.$ value of $7.9 \mu \mathrm{g} / \mathrm{mL}$ ) being more active than those made with black berries ( $\mathrm{IC}_{50}$ value of $17.1 \mu \mathrm{g} / \mathrm{mL}$ ). Opposite situation was found 
in the hypochlorous acid test where methanolic extracts showed in almost all cases a more potent scavenging activity $\left(\mathrm{IC}_{50}\right.$ values in the range $9.5-45.5 \mu \mathrm{g} / \mathrm{mL}$ ) with respect to the infusion made with red berries $\left(\mathrm{IC}_{50}\right.$ value of $37.0 \mu \mathrm{g} / \mathrm{mL}$ ). On the contrary, the black berries tea exhibited a good activity with an $\mathrm{IC}_{50}$ value of $10.6 \mu \mathrm{g} / \mathrm{mL}$ (Table 3).

$H$. androsaemum is a medicinal plant species containing many polyphenolic compounds, namely flavonoids, and phenolic acids and traditionally employed in the preparation of an infusion used for its diuretic and hepatoprotective activities (Valentão et al., 2004). A previous report investigated the ability of $H$. androsaemum leaf infusion to act as a scavenger of reactive oxygen species (superoxide radical, hydroxyl radical, and hypochlorous acid). The tested infusion mainly exhibited a potent scavenging effect on superoxide radicals, although a non-competitive inhibitory effect on xanthine oxidase was also observed. The infusion also acted as a moderate scavenger of hydroxyl radicals and hypochlorous acid (Valentão et al., 2002). Also our results supported the use of $H$. androsaemum in folk medicine to prepare teas with diuretic and antihepatotoxic activities.

\section{Cytotoxic Activity}

The cytotoxic activity of methanolic extracts of $H$. androsaemum fruits were evaluated on tumor cell lines by MTT assay. Three human cell lines, a malignant melanoma cell line (A375), a breast adenocarcinoma cell line (MDA-MB 231), and colon carcinoma cell line (HCT116), were treated with different concentrations of extracts for $72 \mathrm{~h}$. As shown in Table 4, extracts were active against all three tumor cell lines tested and induced a concentration-dependent inhibitory effect in the dilution range $1.56-200 \mu \mathrm{g} / \mathrm{mL}$. Results showed that the highest activity was observed on HCT116 cell line, with a $\mathrm{IC}_{50}$ value of $8.40 \mu \mathrm{g} / \mathrm{mL}$ for black berries extract, while red berries extract resulted less active on all cell lines tested $\left(\mathrm{IC}_{50}\right.$ values in the range $19.40-32.29 \mu \mathrm{g} / \mathrm{mL}$ ). Analysis of secondary metabolites put in evidence the presence of polyphenols, especially shikimic acid, chlorogenic acid, neochlorogenic acid, and 3,5-di-O-caffeoylquinic acid as the main components of fruit methanolic extracts. Chlorogenic acid is reported cytotoxic on human oral tumor cell lines but at high concentrations (HSG, HSC-2, and HGF; IC $_{50}$ values of $1.4,1.3$, and $2.3 \mathrm{mM}$, respectively; Jiang et al., 2000). The same low cytotoxic activity was reported for shikimic acid on $\mathrm{CHO}, 3 \mathrm{~T} 3$, and NRK cell lines (Ngomuo and Jones, 1996). 3,5-Dicaffeoylquinate inhibited proliferation in a dose-dependent manner as detected by MTT assays using Hela cells ( $\mathrm{Hu}$ et al., 2014). Also flavonoids present in fruit extracts as catechin, epicatechin, and rutin were able to inhibit MDA-MB 231 and HCT116 proliferation at concentrations higher than $100 \mu \mathrm{M}$ (Hayes et al., 2006; Li et al., 2009). Quercitrin has antiproliferative and apoptotic effect on colon cancer cells (Cincin et al., 2015). Given the cytotoxic properties reported in literature for xanthones (Bennet and Lee, 1989; Vieira and Kijjoa, 2005; Demirkiran, 2007), 1,2,3,5tetrahydroxyxanthone may also contribute to the final effect observed on tumor cells. Our data confirm the properties of $H$. androsaemum to inhibit the proliferation of colon tumor
TABLE 4 | Cytotoxicity on tumor cells of the methanolic extracts from $H$. androsaemum berries.

\begin{tabular}{lccc}
\hline Extracts & \multicolumn{3}{c}{ Cell line $\left(\mathbf{I C}_{\mathbf{5 0}} \boldsymbol{\mu \mathbf { g } / \mathbf { m L } ) ^ { \mathbf { a } }}\right.$} \\
\cline { 2 - 4 } & $\mathbf{A 3 7 5}^{\mathbf{b}}$ & MDA-MB 231 & HCT116 $^{\mathbf{d}}$ \\
\hline Black berries & 19.31 & 12.88 & 8.40 \\
95\% C.I. & $18.77-19.86$ & $12.33-13.45$ & $8.07-8.74$ \\
Red berries & 32.29 & 30.05 & 19.40 \\
95\% C.I. & $31.45-33.16$ & $26.77-33.74$ & $18.43-20.42$ \\
POSITIVE CONTROL & & & \\
Cisplatin & 0.38 & 2.57 & 2.42 \\
95\% C.I. & $0.31-0.47$ & $2.23-3.05$ & $2.08-2.91$ \\
\hline
\end{tabular}

${ }^{a} / C_{50}=$ The concentration of compound that affords a $50 \%$ reduction in cell growth (after $72 \mathrm{~h}$ of incubation).

${ }^{b}$ Human malignant melanoma cell line.

${ }^{c}$ Human breast adenocarcinoma cell line.

a Human colon carcinoma cell line.

e Confidence interval.

cell lines as reported by Xavier et al. (2012). Aqueous extract of $H$. androsaemum leaves, tested on two human colon cancerderived cell lines, HCT15 and CO115, inhibits proliferation and induced apoptosis through MAP kinases and PI3K/Akt pathway. The phenolic components of the $H$. androsaemum fruits methanolic extracts could explain the cytotoxic activity on tumor cells. Although polyphenols are generally recognized as antioxidants, they also act as prooxidants inducing DNA degradation in the presence of metal ions such as copper. Copperdependent prooxidant mechanism of action of polyphenols accounts for their observed chemopreventive properties, as also for their preferential cytotoxicity toward cancer cells (Khan et al., 2012).

In accordance with the US NCI criterion of anticancer activities (Boik, 2001), the $H$. androsaemum berries extracts may be considered as a potential source of cytotoxic drug, as they showed $\mathrm{IC}_{50}$ values below $20 \mu \mathrm{g} / \mathrm{mL}$.

\section{Immunomodulatory Activity}

The immunomodulatory activity of $H$. androsaemum red berries was evaluated by the in vitro proliferation assay of pig's PBMC which were stimulated with decreasing dilutions of red berries extract. In the first experiment, the two higher concentrations of red berries methanolic extracts tested $(20$ and $10 \mu \mathrm{g} / \mathrm{mL}$, respectively), after 5 days of culture, revealed a cytotoxic effect that destroyed all the cells. Whereas, as shown in Figure 2, an immunodulatory effect started to be seen by using concentrations from 6 to $0.4 \mu \mathrm{g} / \mathrm{mL}$.

Indeed, at the latter concentrations, while the addition of fruit extract to the unstimulated cells continued to elicit an inhibitory/cytotoxic (apoptosis has not been investigated in this study) effect on their proliferation, on the cells activated by PHA and PWM, the fruit extract elicited an increased proliferation response.

The dosage of $6 \mu \mathrm{g} / \mathrm{mL}$ of fruit extract gave the highest proliferative response on cells co-stimulated by PWM, possibly $\mathrm{B}$ cells. However, by decreasing the dosage of $H$. androsaemum 


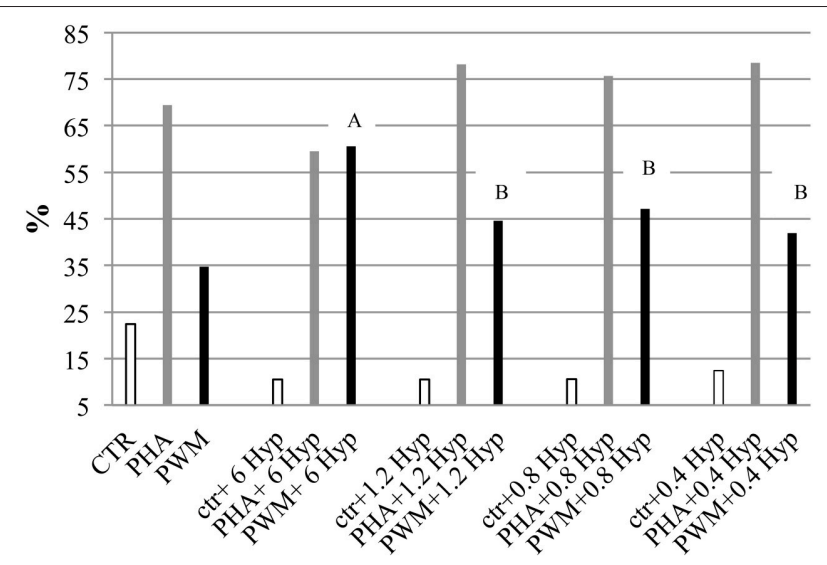

FIGURE 2 | Pig peripheral blood mononuclear cells (PBMC) proliferation assay monitored by CFSE labeling in response to in vitro stimulation with different dosage of $\boldsymbol{H}$. androsaemum methanolic fruit extracts (expressed in $\mu \mathrm{g} / \mathrm{ml}$ ) \pm mitogen or activator. Data are shown as means (standard error: 6.27) and it was observed a significant effect of interaction between mitogen/activator and fruit extract dosages $(P<0.006)$. $A, B$ : different letters denote the significant differences of increased proliferation vs. the basal values (CTR, PHA, and PWM cells cultured without fruit extracts, but only mitogen/activator) obtained by adding different concentrations of $\mathrm{H}$. androsaemum methanolic fruit extracts, $P<0.005$

fruits, the cells co-stimulated by PHA too increased their proliferation responses vs. control ones (CTR + PHA). The polyclonal activator of T cells (PHA) induced the higher PBMC proliferation response when combined with the lower fruit extract dosages investigated. Although, the treatment (different fruit extract concentrations) did not show a significant effect on the mean percentages resulted by the proliferative assay, a significant interaction between fruit extract dosage and mitogen/activator was observed $(P<0.01)$. Indeed, the PI of cells stimulated with PWM and $6 \mu \mathrm{g} / \mathrm{mL}$ of $H$. androsaemum extract was significantly higher than those obtained by cells cultured with PWM and 1.2, 0.8 , and $0.4 \mu \mathrm{g} / \mathrm{mL}$ of fruit extract, respectively.

At the dosage of $6 \mu \mathrm{g} / \mathrm{mL}$, the methanolic extract of red berries seemed to induce an immune deviation from cellular immunity to humoral responses that has been already observed by other authors in mice treated with hydroalcoholic extract of $H$. perforatum (Abhtai Froushani et al., 2015). The observed results may be correlated with the high levels of shikimic acid found in red berries. Shikimic acid was found effective, even in low doses, in the modulation of leukocyte activity (Bertelli et al., 2008). This compound, either alone or in combination with quercitin, was able to modulate the release of IL-6 and IL-8 from PBMCs. Since xanthones are molecules capable to modulate antiinflammatory and anti-bacterial activities (Bennet and Lee, 1989), also the presence of 1,2,3,5-tetrahydroxyxanthone in the fruits of $H$. androsaemum may be taken into account for the observed activity.

The possibility to modulate the immune responses represents a very important goal when situations of immunodeficiency should be activated or a selective immunosuppression has to be induced, for example, in autoimmune disorders.

\section{CONCLUSION}

The present study represents a comprehensive phytochemical and biological investigation of fruits of $H$. androsaemum, a wild medicinal plant of the Mediterranean region. On the above, the balsamic period was identified as the plant produces red berries. The latter were proven to be rich in shikimic acid and in phenolic compounds, especially chlorogenic acids. Moreover, the pigment giving the red color to the fruit pericarp was structurally determined as 1,2,3,5-tetrahydroxyxanthone that is reported for the first time for Hypericum species. Hence, $H$. androsaemum berries can be a good source of this molecule with potential applications at industrial level. Overall, the high antioxidant potential of tutsan berries was demonstrated and could be achieved directly by consumption of infusions or by incorporating polar extracts in antioxidant formulations. The cytotoxicity of methanolic extracts on tumor cell lines, especially on colon carcinoma, make $H$. androsaemum berries a potential candidate as a functional food having beneficial effects against tumors correlated with a life style characterized by the so-called "western diet." Data from immunomodulatory assay suggest that red berries of $H$. androsaemum may represent a promising and natural strategy to modulate the immune system, although the mechanisms of action remain to be clarified. The obtained results could explain the past and current usage of $H$. androsaemum as food and in folk medicine; also they may support its further uses in health and in nutrition as a functional food.

\section{AUTHOR CONTRIBUTIONS}

GC, HPLC analysis; AA, immunomodulatory assay; DB, immunomodulatory assay; $\mathrm{AB}$, column chromatography and NMR; MB, MTT assay; CF, column chromatography and NMR; RI, HPLC analysis; FP, plant collection; LQ, MTT assay; GS, HPLC analysis; BT, antioxidant experiments; AV, column chromatography and NMR; SV, HPLC analysis.

\section{ACKNOWLEDGMENTS}

This work was supported by the FAR 2014-2015 (FPI000044Fondo di Ateneo per la Ricerca) of the University of Camerino. Authors thank Dr. Marzia Innocenti from the University of Florence for her support in the chemical analysis, and Dr. Kevin Cianfaglione from the University of Camerino for his help in sample collections.

\section{SUPPLEMENTARY MATERIAL}

The Supplementary Material for this article can be found online at: http://journal.frontiersin.org/article/10.3389/fpls.2016. 00232 


\section{REFERENCES}

Abhtai Froushani, S. M., Galee, H. E. G., Khamisabadi, M., and Lotfallahzades, B. (2015). Immunomudulatory effects of hydroalcoholic extract of Hypericum perforatum. Avicenna J. Phytomed. 5, 62-68.

Allen, D. A., and Hatfield, G. (2004). Medicinal Plants in Folk Tradition. An Ethnobotany of Britain and Ireland. Portland, OR: Timber Press, Inc.

Aziz, N., Sauve, R. J., Long, D., and Cherry, M. (2006). Genetic and Phytochemical Diversity Assessment Among Eleven Hypericum Accessions via AFLP and HPLC Analyses. J. Herbs Spices Med. Plants 12, 97-105. doi: 10.1300/J044v12n01_09

Bennet, G. J., and Lee, H.-H. (1989). Xanthones from Guttiferae. Phytochemistry 28, 967-998. doi: 10.1016/0031-9422(89)80170-0

Bertelli, A. A. E., Mannari, C., Santi, S., Filippi, C., Migliori, M., and Giovannini, L. (2008). Immunomodulatory activity of shikimic acid and quercitin in comparison with oseltamivir (Tamiflu) in an "in vitro" model. J. Med. Virol. 80, 741-745. doi: $10.1002 / j m v .21072$

Boik, J. (2001). Natural Compounds in Cancer Therapy. Princeton, MN: Oregon Medical Press.

Bonkanka, C. X., Smelcerovic, A., Zuehlke, S., Rabanal, R. M., Spiteller, M., and Sánchez-Mateo, C. C. (2008). HPLC-MS analysis of anti-oedematogenic activity of Hypericum grandifolium Choisy (Hypericaceae). Planta Med. 74, 719-725. doi: 10.1055/s-2008-1074526

Caprioli, G., Cortese, M., Odello, L., Ricciutelli, M., Sagratini, G., Tomassoni, G., et al. (2013). Importance of Espresso coffee machine parameters on the extraction of chlorogenic acids in a certified Italian Espresso by Using SPEHPLC-DAD. J. Food Res. 2, 55-64. doi: 10.5539/jfr.v2n3p55

Chen, W.-C., Liou, S.-S., Tzeng, T.-F., Lee, S.-L., and Liu, I.-M. (2013). Effect of topical application of chlorogenic acid on excision wound healing in rats. Planta Med. 79, 616-621. doi: 10.1055/s-0032-1328364

Cho, A.-S., Jeon, S.-M., Kim, M.-J., Yeo, J., Seo, K.-I., Choi, M.-S., et al. (2010). Chlorogenic acid exhibits anti-obesity property and improves lipid metabolism in high-fat diet-induced-obese mice. Food Chem. Toxicol. 48, 937-943. doi: 10.1016/j.fct.2010.01.003

Chung, H. S. (2003). Inhibition of monamine oxidase by a flavone and its glycoside from Ixeris dentata Nakai. Nutr. Food 8, 141-144. doi: 10.3746/jfn.2003.8.2.141

Cincin, Z. B., Unlu, M., Kiran, B., Bireller, E. S., Baran, Y., and Cakmakoglu, B. (2015). Apoptotic effects of quercitrin on DLD-1 colon cancer cell line. Pathol. Oncol. Res. 21, 333-338. doi: 10.1007/s12253-014-9825-3

Clifford, M. N. (1999). Chlorogenic acids and other cinnamates - nature, occurrence and dietary burden. J. Sci. Food Agric. 79, 362-372.

Dapkevicius, A., Venskutonis, R., Van Beek, T. A., and Linssen, P. H. (1998). Antioxidant activity of extracts obtained by different isolation procedures from some aromatic herbs grown in Lithuania. J. Sci. Food Agric. 77, 140-146.

Demirkiran, O. (2007). Xanthones in Hypericum: synthesis and biological activities. Top. Heterocycl. Chem. 9, 139-178. doi: 10.1007/7081_2007_079

Dias, A. C. P., Seabra, R. M., Andrade, P. B., Ferreres, F., and Fernandes-Ferreira, M. (2000). Xanthone biosynthesis and accumulation in calli and suspended cells of Hypericum androsaemum. Plant Sci. 150, 93-101. doi: 10.1016/S01689452(99)00178-8

Dopico-Garcia, M. S., Castro-Lopez, M. M., Lopez-Vilarino, J. M., GonzalezRodriguez, M. V., Valentao, P., Andrade, P. B., et al. (2011). Natural extracts as potential source of antioxidants to stabilize polyolefins. J. Appl. Polym. Sci. 119, 3553-3559. doi: 10.1002/app.33022

Dragović-Uzelac, V., Bursać Kovačević, D., Levaj, B., Pedisić, S., Mezak, M., and Tomljenoviæ, A. (2009). Polyphenols and antioxidant capacity in fruits and vegetables common in the croatian diet. Agric. Conspectus Scientificus 74, $175-179$.

Han, J.-T., Bang, M.-H., Chun, O.-K., Kim, D.-O., Lee, C.-Y., and Baek, N.-I. (2004). Flavonol glycosides from the aerial parts of Aceriphyllum rossii and their antioxidant activities. Arch. Pharm. Res. 27, P390-P395. doi: 10.1007/BF02980079

Han, T., Li, H., Zhang, Q., Zheng, H., and Qin, L. (2006). New thiazinediones and other components from Xanthium strumarium. Chem. Nat. Comp. 42, 567-570. doi: 10.1007/s10600-006-0215-2

Hayes, C. J., Whittaker, B. P., Watson, S. A., and Grabowska, A. M. (2006). Synthesis and preliminary anticancer activity studies of C4 and C8-modified derivatives of catechin gallate (CG) and epicatechin gallate (ECG). J. Org. Chem. 71, 9701-9712. doi: 10.1021/jo061740e

$\mathrm{Hu}, \mathrm{T}$., He, X. W., and Jiang, J. G. (2014). Functional analyses on antioxidant, antiinflammatory, and antiproliferative effects of extracts and compounds from Ilex latifolia Thunb., a Chinese bitter tea. J. Agric. Food Chem. 62, 8608-8615. doi: $10.1021 / \mathrm{jf} 501670 \mathrm{v}$

Jiang, Y., Kusama, K., Satoh, K., Takayama, F., Watanabe, S., and Sakagami, H. (2000). Induction of cytotoxicity by chlorogenic acid in human oral tumor cell lines. Phytomedicine 7, 483-491. doi: 10.1016/S0944-7113(00)8 0034-3

Khan, H. Y., Zubair, H., Ullah, M. F., Ahmad, A., and Hadi, S. M. (2012). A prooxidant mechanism for the anticancer and chemopreventive properties of plant polyphenols. Curr. Drug Targets 13, 1738-1749. doi: $10.2174 / 138945012804545560$

Kitanov, G. M. (2001). Hypericin and pseudohypericin in some Hypericum species. Biochem. Syst. Ecol. 29, 171-178. doi: 10.1016/S0305-1978(00)00032-6

Lamaison, J. L., and Carnat, A. (1990). Teneurs en principaux flavonoides des fleurset des feuilles de Crataegus monogyna Jacq. et de Crataegus laevigata (Poiret) DC. Pharm. Acta Helv. 65, 315-320.

Li, L., Henry, G. E., and Seeram, N. P. (2009). Identification and bioactivities of resveratrol oligomers and flavonoids from Carex folliculata seeds. J. Agric. Food Chem. 57, 7282-7287. doi: 10.1021/jf901716j

Liu, F. C., Coimbra, R., Hoyt, D. B., and Junger, W. G. (1996). Proliferation assays with human, rabbit, rat, and mouse lymphocytes. In Vitro Cell. Dev. Biol. Anim. 32, 420-523. doi: 10.1007/BF02722976

Lu, Y., and Foo, L. Y. (2000). Flavonoid and phenolic glycosides from Salvia officinalis. Phytochemistry, 55, 263-267. doi: 10.1016/S0031-9422(00)00309-5

Manguro, L. O. A., Ugi, I., Lemmen, P., and Hermann, R. (2003). Flavonol glycosides of Warburgia ugandensis leaves. Phytochemistry 64, 891-896. doi: 10.1016/S0031-9422(03)00374-1

Mulinacci, N., Ieri, F., Giaccherini, C., Innocenti, M., Andrenelli, L., Canova, G., et al. (2008). Effect of cooking on the anthocyanins, phenolic acids, glycoalkaloids and resistant starch content in two pigmented cultivars of Solanum tuberosum L. J. Agric. Food Chem. 56, 11830-11837. doi: $10.1021 / \mathrm{jf} 801521 \mathrm{e}$

Ngomuo, A. J., and Jones, R. S. (1996). Cytotoxicity studies of quercetin, shikimate, cyclohexanecarboxylate and ptaquiloside. Vet. Hum. Toxicol. 38, 14-18.

Nielsen, H., and Arends, P. (1979). Xanthone constituents of Hypericum androsaemum. J. Nat. Prod. 42, 301-304. doi: 10.1021/np5000 $3 \mathrm{a} 012$

Perrone, R., De Rosa, P., De Castro, O., and Colombo, P. (2013). Leaf and stem anatomy in eight Hypericum species (Clusiaceae). Turk. J. Bot. 37, 847-858. doi: 10.3906/bot-1206-22

Peterson, D. M., Hahn, M. J., and Emmons, C. L. (2002). Oat avenanthramides exhibit antioxidant activities in vitro. Food Chem. 79, 473-478. doi: 10.1016/S0308-8146(02)00219-4

Phillips, R. (1977). Wild Flowers of Britain. London, UK: Pan Books.

Quassinti, L., Lupidi, G., Maggi, F., Sagratini, G., Papa, F., Vittori, S., et al. (2013). Antioxidant and antiproliferative activity of Hypericum hircinum L. subsp. majus (Aiton) N. Robson essential oil. Nat. Prod. Res. 27, 865-868. doi: $10.1080 / 14786419.2012 .677044$

Sagratini, G., Ricciutelli, M., Vittori, S., Öztürk, N., Öztürk, Y., and Maggi, F. (2008). Phytochemical and antioxidant analysis of eight Hypericum taxa from Central Italy. Fitoterapia 79, 210-213. doi: 10.1016/j.fitote.2007.11.011

Scarpati, M. L., Oriente, G., and Panizzi, L. (1957). Sui costituenti caffeici del carciofo. Ann. Chim. 47, 150.

Schmidt, W., El-Mawla, A. M. A., Wolfender, J.-L., Hostettmann, K., and Beerhues, L. (2000). Xanthones in cell cultures of Hypericum androsaemum. Planta Med. 66, 380-381. doi: 10.1055/s-2000-8542

Singleton, V. L., and Rossi, J. A. J. (1965). Colorimetry of total phenolics with phosphomolybdic-phosphotungstic acid reagents. Am. J. Enol. Vit. 16, 144-153.

Trong Tuan, D., Thai Trung, D., Phi Hung, N., Eunhee, K., Phuong, T. T., and Won, K. O. (2012). Xanthones from Polygala karensium inhibit neuraminidases from influenza A viruses. Bioorg. Med. Chem. Lett. 22, 3688-3692. doi: 10.1016/j.bmcl.2012.04.028

Valentão, P., Carvalho, M., Fernandes, E., Carvalho, F., Andrade, P. B., Seabra, R. M., et al. (2004). Protective activity of Hypericum androsaemum infusion 
against tert-butyl hydroperoxide-induced oxidative damage in isolated rat hepatocytes. J. Ethnopharmacol. 92, 79-84. doi: 10.1016/j.jep.2004.02.004

Valentão, P., Fernandes, E., Carvalho, F., Andrade, P. B., Seabra, R. M., Bastos, M. D. L. (2002). Antioxidant Activity of Hypericum androsaemum infusion: scavenging activity against superoxide radical, hydroxyl radical and hypochlorous acid. Biol. Pharm. Bull. 25, 1320-1323. doi: 10.1248/bpb.25.1320

Vieira, L. M. M., and Kijjoa, A. (2005). Naturally-Occurring Xanthones: recent developments. Curr. Med. Chem. 12, 2413-2446. doi: 10.2174/092986705774370682

Weiss, S. J., Klein, R., Slivka, A., and Wei, M. J. (1982). Chlorination of Taurine by Human Neutrophils. J. Clin. Investig. 70, 598-607. doi: 10.1172/JCI110652

Xavier, C. P., Lima, C. F., Fernandes-Ferreira, M., and Pereira-Wilson, C. (2012). Hypericum androsaemum water extract inhibits proliferation in human colorectal cancer cells through effects on MAP kinases and PI3K/Akt pathway. Food Funct. 3, 844-852. doi: 10.1039/c2fo10226a

Xiao, C., Dai, H., Liu, H., Wang,Y., and Tang, H. (2008). Revealing the metabolomic variation of rosemary extracts using $1 \mathrm{H}$ NMR spectroscopy and multivariate data analysis. J. Agric. Food Chem. 56, 10142-10153. doi: $10.1021 / \mathrm{jf} 8016833$
Zorzetto, C., Sánchez-Mateo, C. C., Rabanal, R. M., Lupidi, G., Petrelli, D., Vitali, L. A., et al. (2015). Phytochemical analysis and in vitro biological activity of three Hypericum specie from the Canary Islands (Hypericum reflexum, Hypericum canariense and Hypericum grandifolium). Fitoterapia 100, 95-109. doi: 10.1016/j.fitote.2014. 11.013

Conflict of Interest Statement: The authors declare that the research was conducted in the absence of any commercial or financial relationships that could be construed as a potential conflict of interest.

Copyright (c) 2016 Caprioli, Alunno, Beghelli, Bianco, Bramucci, Frezza, Iannarelli, Papa, Quassinti, Sagratini, Tirillini, Venditti, Vittori and Maggi. This is an openaccess article distributed under the terms of the Creative Commons Attribution License (CC BY). The use, distribution or reproduction in other forums is permitted, provided the original author(s) or licensor are credited and that the original publication in this journal is cited, in accordance with accepted academic practice. No use, distribution or reproduction is permitted which does not comply with these terms. 